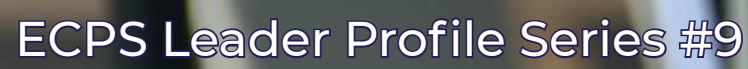

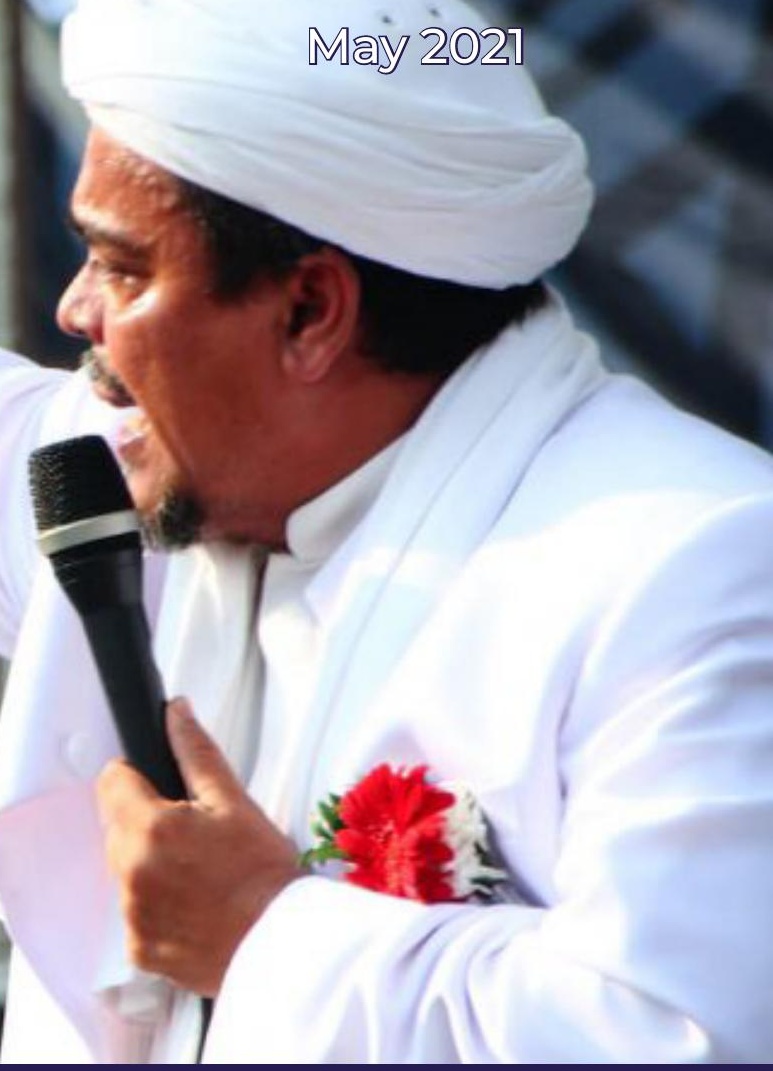

AUTHORS: Ihsan Yilmaz \& Greg Barton

Populism, Violence, and Vigilantism in Indonesia: Rizieq Shihab and His Far-Right Islamist Populism

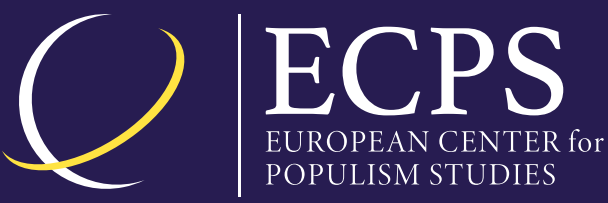




\section{Populism, Violence, and Vigilantism in Indonesia: Rizieq Shihab and His Far- Right Islamist Populism}

BY IHSAN YILMAZ \& GREG BARTON

\section{ABSTRACT}

Muhammad Rizieq Shihab has been one of the most well-known faces of the far-right in Indonesia since the late 1990s. As a radical Islamist scholar with links to Saudi Arabia, Shihab has spent the last three decades as an anti-state voice of the "pious Muslim majority" in Indonesia. He claims to position himself as a "righteous" and "fearless" leader who is dedicated to defending Islam — the faith of "the people." In 2020 Shihab was arrested for holding large public gatherings, as part of his 'moral revolution' campaign, in the middle of pandemic lockdowns. However, his radical Salafist message continues to inspire thousands to action.

IHSAN YILMAZ is Research Professor and Chair of Islamic Studies and Intercultural Dialogue at the Alfred Deakin Institute for Citizenship and Globalisation (ADI), Deakin University, Melbourne, Australia.

GREG BARTON is one of Australia's leading scholars of both modern Indonesia and of terrorism and countering violent extremism. For more than 25 years he has undertaken extensive research on Indonesia politics and society, especially of the role of Islam as both a constructive and a disruptive force. He has been active in the inter-faith dialogue initiatives and has a deep commitment to building understanding of Islam and Muslim society

ECPS Leader Profile Series offer analyses of political leaders and prominent public figures with populist tendencies. Unless otherwise indicated, the views expressed by the author are only attributable him and not to any institution with which they are associated.

The profile available for free downloading from the ECPS website (www. populismstudies.org)

(C)ECPS 2021 


\section{Table of contents}

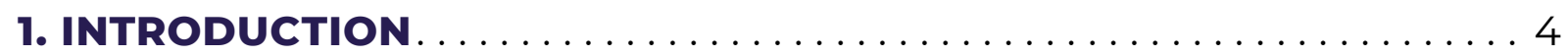

2. THE ROOTS OF SHIHAB'S ISLAMIST IDEOLOGY $\ldots \ldots \ldots \ldots \ldots 5$

3. INDONESIA'S SALAFIST PROTÉGÉ $\ldots \ldots \ldots \ldots \ldots \ldots \ldots \ldots \ldots$

4. SHIHAB'S CALL FOR VIGILANTISM $\ldots \ldots \ldots \ldots \ldots \ldots \ldots$

5. THE FPI A SURROGATE WELFARE SYSTEM $\ldots \ldots \ldots \ldots \ldots \ldots \ldots$

6. SHIHAB'S TARGETING OF AHOK IN POLITICAL LOBBYING ....... 11

7. SHIHAB IMPRISONMENT AND THE FUTURE OF SALAFISM IN

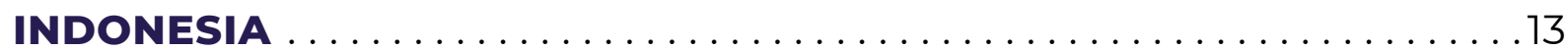

CONCLUSION ...............................................

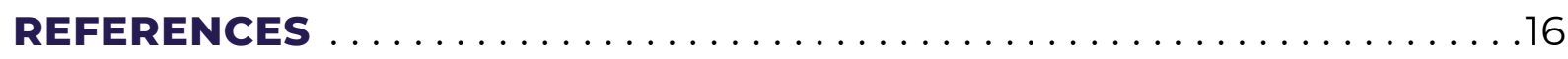




\section{INTRODUCTION}

Muhammad Rizieq Shihab-more commonly known as Habib Rizieq-is one of the most well-known faces of the far-right in Indonesia. He has been a permanent fixture in Indonesian popular culture since the late 1990s but drew international media coverage in late 2016 and early 2017, where he spearheaded mass protests intended to derail the election campaign of Basuki Tjahaja Purnama (widely known by his nickname "Ahok"), the ethnic-Chinese, Christian governor of Jakarta. Billed as "Protests to defend the Qur'an," they were more widely known as the "2/12 protests" because the largest of the protests, which saw over 500,000 people flood the center of the national capital, was held on 2 December 2016.

In 2020, Shihab again made headlines when he was arrested for holding large public gatherings, as part of his "moral revolution" campaign, in the middle of COVID-19 pandemic lockdowns. As a radical Islamist scholar with links to Saudi Arabia, Shihab has spent the last three decades as an anti-state voice of the "pious Muslim majority" in Indonesia. He claims to position himself as a "righteous" and "fearless" leader who is dedicated to defending Islam-the faith of "the people." 


\section{The Roots of Shihab's Islamist Ideology}

One of the most important political developments of the twentieth century for Muslim majority populations across the world was the fall of the Ottoman Empire (Gubbay, 2000; Lewis, 1980). The decline of this vast empire, as with other great empires, occurred incrementally. It entered a nearly two-century-long twilight phase before it was broken up following its decisive defeat in the First World War (Gubbay, 2000; Lewis, 1980). The majority of Sunni Muslims across the world traditionally saw the Ottoman Empire as representing a modern continuation of the Muslim caliphate, which started with the leadership of Prophet Muhammad.

When the symbolic figurehead of the Sunni Muslim world suddenly ceased to exist, the gap was soon fulfilled by the relatively new leadership of the Saud family who became the rulers of modern-day Saudi Arabia (Dillon, 2009; Gubbay, 2000; Lewis, 1980). The kingdom had itself been part of the Ottoman Empire. Saudi Arabia hosts two of the holiest cities in the Islamic faith, Mecca and Medina, to which Muslim pilgrims pay annual visits in the form of Haj or umrah.

Saudi Arabia's symbolic significance derives from it being the home of the two holy cities and custodian of the Kabah. While the Ottomans were, like the Saudis, followers of Sunni Islam, they adhered to the teachings of Imam Abu Hanifa. Thus, the Ottomans followed the Hanafi school of thought, and in approaching the Qur'an, the sunnah and the hadithsought to understand Islam using the methods of ijma (consensus) and qiyas (deduction from analogy) (Baer, Makdisi, and Shryock, 2009; Gawrych, 1983). This idea of interpretation using deduction and consensus has made the Hanafi school more flexible and open to adaptation to the changing times than the Hanbali school followed in Saudi Arabia.

In addition to the Hanafi influence, the societies of the Ottoman Empire were also influenced by thousands of Sufi teach- ers, writers, and mystics (Baer, Makdisi, \& Shryock, 2009; Gawrych, 1983). The Sufi approach to Islam believes in establishing a direct connection between the higher power and the individual and does not solely rely on sacred texts and religious rituals to build this connection (Baer, Makdisi, \& Shryock, 2009; Gawrych, 1983). Hanafi approaches to interpretation and the influences of Sufi thought and practice combined to make the religious culture of the Ottoman Empire generally open and tolerant. There were a great variety of sects and Islamic traditions welcomed in the empire. Still, there were also many opportunities for non-Muslims to play important functional roles, not just in society but also in administrative affairs.

In contrast with Ottoman society's pluralistic and flexible practices, the Al Saud dynasty took a narrower and more rigid approach as followers of the literalist new school of Sunni thought established by Muhammad ibn Abd al-Wahhab. In the eighteenth century, Muhammad bin Saud, the founder of the Al Saud dynasty, joined forces with Muhammad ibn Abd al-Wahhab. The former accepted the latter's ideology and approach to religious life in exchange for al-Wahhab's endorsement of the legitimacy of the Al Saud leadership. The Wahhabi movement, or Salafi school of thought, is markedly more stringent than the schools of thought that came before it as it was formed as a "reformist" movement to "purify" Islam from what is thought of as "additional" rituals (Dillon, 2009).

Over the years, Salafi hardliners have propagated the idea that it is only through their legalistic approach that true adherence to the Islamic ideal of monotheistic worship is possible. The Salafi take a negative and, at times, hostile attitude and behavior toward the various sub-sects of Sunni Islam and toward Shia Muslims and non-Muslims (Dillon, 2009). Since the mid-twentieth century, Saudi Arabia has been able to spread its brand of Islam through its petrodollar wealth generated from the fossil fuel industry. Leveraging the cultural capital of its guardianship of the sacred sites and drawing liberally on its financial capital to disseminate its ideology by financing various educational organizations, Saudi Arabia has tried to in- 
fluence Muslim-majority countries such as Pakistan, Indonesia, Bangladesh, Afghanistan, and Egypt to accept Arab culture and Salafi Wahabism as being essential to authentic expressions of Islam.

In this endeavor, education represents an essential vehicle for propagation.

Funding of madrasa (religious schools) and even universities-such as the International Islamic Universities-through the Organisation of Islamic Cooperation (OIC) and sponsoring scholarships for students from Muslim countries to gain religious education at King Saud University constitute key elements of Saudi influence (Junior, 2017; Ghoshal, 2010).

In observing the presence of Saudi influence in Asia, Ghoshal (2010) comments, "this process of homogenization and regimentation-a process I would like to call the 'Arabization' of Islam-puts greater emphasis on rituals and codes of conduct than on substance, through the Wahhabi and Salafi creeds, a rigidly puritanical branch of Islam exported from, and subsidized by, the Kingdom of Saudi Arabia." As a result, in Asia, Muslim-majority countries have witnessed growing radicalization since the 1980s. Various leaders trained at Saudi-funded and affiliated institutions have continued to spread the hardline narrative of Wahhabism (Freeman, Ellena \& Kator-Mubarez, 2021; Benjamin, 2016).

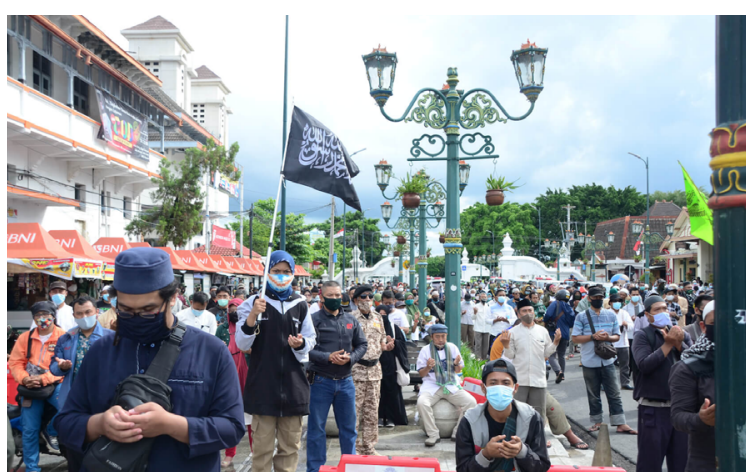

Indonesia

\section{Indonesia's Salafist Protégé}

As one of the most well-known faces of the far-right in Indonesia, Muhammad Rizieq Shihab positions himself as a "righteous" and "fearless" leader who is dedicated to defending Islam-the faith of "the people." In this quest, he formed the Front Pembela Islam (FPI) in 1998 (Jahroni, 2004). Shihab has used his knowledge of sharia law to declare himself the "grand imam" of Indonesia, dressed in symbolic white-a "pure" color in Islam-with either a green turban (reflecting the color of the shrine of Muhammad) or white turban to symbolize the "purity" and "truth" of his message. While assuming an anti-state approach, Shihab has nevertheless acted as a lobbyist for mainstream right-wing populist parties by swaying voters their way.

In the typical manner of a populist leader, Shihab seeks a direct connection with "the people." Not only does he use his fluent Arabic and standard religious rhetoric to incite intense emotions in the crowd, but he also draws upon his origin story of "humble beginnings" to relate to his audience. The wearing of plain clothes, the use of "crude" or simplistic language, and the cracking of jokes at rallies while talking about the "evils" that plague the Muslims of the world are his populist hallmarks (Maulia, 2020). Like other populist leaders, Shihab channels the "common person" persona to successfully position himself against the "corrupt elite" with the underlying assumption that "the elite" cannot relate to, and thus do not care about, "the people" (Yilmaz, 2021a; McDonnell \& 
Ondelli, 2020; Nai \& Coma, 2019). When Narendra Modi, for example, takes pride in his humble beginnings as a chai wala (tea stall owner) or when Recep Tayyip Erdogan calls himself a "Black Turk" (Yilmaz, $2021 b)$ to relate with the conservative and historically disenfranchised Muslims of small Anatolian towns, both are relating to the "common people" by identifying themselves as being an approachable and relatable leader in contrast to "the elite" and "corrupt" who do not speak, dress, behave and at times look the same way as "the people."

Rizieq Shihab lost his father as a child and was raised in modest circumstances by his widowed young mother. He gained his school degree at the Salafist Lembaga Ilmu Pengetahuan Islam dan Bahasa Arab (LIPIA), which is one of a chain of Islamic schools funded by Saudi Arabia in Indonesia (Varagur, 2020). At LIPIA, Shihab was exposed to "true Islamic teachings" mixed with state curriculum guidelines. Varagur's (2020) investigation into Saudi influence in Indonesia revealed that LIPIA uses a blended curriculum employing Wahhabi ideology and the social ideas of "Muslim Brotherhood-oriented political thinkers." Consequently, LIPIA produces both Salafi teachers and Islamist social leaders. Like Shihab, many other figures have emerged from this milieu as Islamist leaders occupying prominent roles in domestic politics, such as Hidayat Nur Wahid, the leader of the Prosperous Justice Party (PKS), aligned with the Egyptian Muslim Brotherhood (Varagur, 2020).

Being well-versed in Arabic texts and Salafi teaching, it was not hard for Shihab to earn a scholarship at the King Saud University in Saudi Arabia, where he continued his studies of sharia and Islam. Following his studies, he spent some time teaching in Saudi Arabia and later in Indonesia at Salafi educational institutes (Jahroni, 2004). As a popular preacher in the field of tableeg (spreading the religion), Shihab was a fixture in various Jakarta suburbs at Majelis Ta'lim (religious lectures) (Rijal, 2020; Woodward, 2012). Via these gatherings, Shihab built his social capital with the locals as a spiritual mentor who was imparting the "right" version of Islam to them. His involvement in Majelis Ta'lim was one of his first opportunities to interact with people outside the school setting to whom he could preach Salafism.

Given the conditions on Java, a densely populated island with wide disparities in wealth and endemic urban poverty, the Islamic ideals of equity and justice preached by popular figures like Shihab have great appeal for the disenfranchised. Yilmaz, Morieson, and Demir (2021) have pointed out that the use of "social justice" by populist Islamist leaders to call out the failure of government is an important theme. Using this notion, Shihab entered Jakarta's politics with one foot in the door with the help of popular Islamic preaching in the 1990s. He made effective use of Salafi idealism to address what conventional and "Western" forms of democracy had failed to deliver for the Indonesian people.

Post-Suharto, as Indonesia returned to democracy in 1998, a plethora of new religious and conservative parties seized the opportunity to campaign and participate in elections. This led to a rise in religious groups forming parties and registering them, including the FPI (Hadiz, 2016). As a counter to growing student-led civil unrest against the regime, right-wing parties were also promoted by the state to counter the protesters on the streets (Hadiz, 2016: 154). With democratic freedoms and encouragement by the state, Indonesia soon saw a marked rise in right-wing parties, of which the FPI was one.

Before 1998, Shihab had a limited audience for his religious lectures. But new political freedoms gave him a chance to use FPI as a populist Islamist party to spread its Salafism to a much wider audience. FPI preaching drew heavily on Salafi romanticization of jihad, which "tend[s] to emphasize the military exploits of the Salaf (the early generations of Muslims) to give their violence an even more immediate divine imperative" (Hamid \& Dar, 2016). As a result, FPI, under the leadership of Shihab, carried out frequent acts of vigilantism under the banner of a "moral jihad" against "the Other" (Woodward, 2012; Jahroni, 2004). 


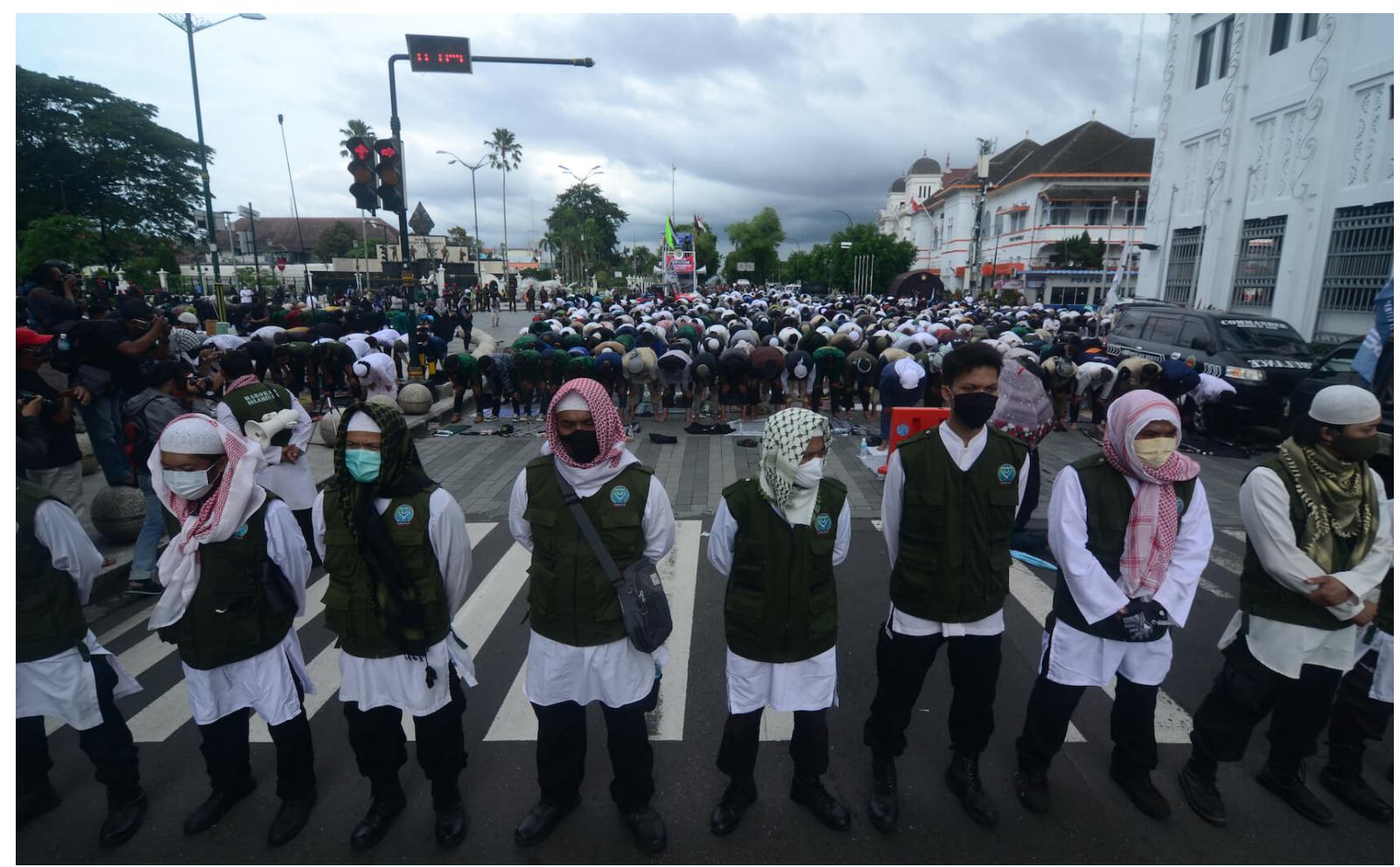

The mass action "Jogja Bergerak untuk Keadilan dan HAM" demands the release of Rizieq Shihab and the investigation of the shooting case of the FPI army in Yogyakarta, Indonesia on December 18, 2020. Photo: Hariyanto Surbakti

\section{Shihab's Call for Vigilantism}

Who constitutes this "Other," one might ask? From Shihab's perspective, "the Other" is not only limited to the political elite of the country. He has constantly categorized liberal Muslims, non-Muslims, and Western countries as "enemies." They are seen as being antagonists of the faith, and their actions are said to constantly endanger Islam at home and across the world. Firmly believing in the call for action, Shihab has called out his followers to pick up arms against "the others." Thus, a core part of FPI's activities has been vigilantism.

Hardline Islamism has been used to spew hatred to those who are seen as the "outsiders." Shihab has used his "anti-establishment agenda" to incite people to take up arms (Mietzner, 2018). His narrative hinges on inciting "fear" among his followers. Given the correlated nature of faith and identity, when the followers perceive a threat to their faith, they feel an ontological crisis looming above their heads. Using this vulnerability by inciting fear and feelings of victimhood as part of the oppressed Muslim ummah, the "faithful" are guided to solutions. In Shihab's case, the narrative is that Indonesian politicians are either mere puppets of the Western powers or are simply incompetent. Thus, to save oneself in this life and the life after, the believer must take action. Since the formation of FPI in 1998, numerous members have been arrested and charged with spreading terror by vandalism (Facal, 2019; Ricklefs, 2012; Jahroni, 2004).

By placing the Qur'an (in line with Wahabi thinking) above the state and the democratically elected government, the FPI has urged its militia members to continue their actions against "the Other" on the ground that it is necessary to bring sharia to Indonesia (Mietzner, 2018; Hadiz, 2016: 112; Wilson, 2015). Hadiz (2016: 112) argues that "[The FPI is] believed to be involved in criminal activity, including racketeering, even as they ardently oppose the presence of 'dens of vice' such as nightclubs, pubs and massage parlours." Shihab has raised a private army of volunteers. The Islamic Defenders Front Militia/ Front Pembela Islam or Laskar Pembela 
Islam (LPI) is the militant wing of Shihab's group, which puts its ideology into action. They are unlike terrorist groups in the sense that they do not use sophisticated weapons to terrorize citizens at various "hot spots" such as nightclubs. However, they believe in the same ideology that "un-Islamic" behavior is threatening Islam and the future of the ummah, and thus action needs to be taken.

Over the years, Shihab has been able to design and organize the LPI militia in a highly systematic manner, with individuals leading paramilitary cells of various sizes just like an army. These are volunteer citizens who dress in paramilitary garb and use their sticks, batons, and shouts of "Allahu Akbar" to terrorize and attack those seen as "Other." The members of the LPI are called "Jundi." Jundi fighters are organized into ranks, with superior officers responsible for anywhere between 25 and 25,000 vigilantes (Jahroni, 2004). Within this militia, the overarching leader is the Imam Besar ("grand imam") namely, Shihab himself-who is the "spiritual guide" for all the actions of the vigilantes (Jahroni, 2004).

The LPI is also known to welcome non-militia members of FPI, such as the volunteers, while purging "hotspots" in the city (Facal, 2019). Sito (2019: 191) notes how Shihab has legitimized violence as the answer to problems faced by Muslims as he "stated that such businesses [i.e., hotspots of vice] ensure only social deviance which are the product of Western secularism (sekularisme), pluralism (pluralisme), and liberalism (liberalisme), shortened as "sepilis." The acronym is a homophone of syphilis, which is intended to mock and draw an equivalency between sexually transmitted diseases and Western culture and capitalism, pegged as the culprit of the economic crisis in 1997 and 1998. Accordingly, over the years, the FPI has claimed that such vigilantism is an expected outcome of upholding the Muslim duty to "promote good and prevent evil."

The militant activities of the FPI have been highly visible ever since its inception. In 1998 various members of its groups were involved in a clash between the ethnic Chinese residents of Ketapang that lead to the death of over a dozen of ethnically Chinese Indonesian Catholics (Bouma, Ling \& Pratt, 2009). Attacks on nightspots, bars, clubs, and suspected LGBTQ+ events have become a hallmark of the group. While the group was banned recently due to its terror sprees, its activities have been able to continue because of the support it has received from law enforcement agencies.

While Indonesia might seem like a peaceful country on the surface, it has long been struggling with reactionary religious forces. In election campaigns, radical Islamism has become an important factor, and public perceptions about modesty, norms, and values are primarily driven by those claiming to act in the name of Islam. Within this context, Shihab has been able to build an alliance with the state security forces (including the police), who are also proactive in their crackdowns on "deviant" groups such as the LGBTQ+ and Ahmadiyya communities. The FPI has been known to carry out the "dirty work" by attacking these groups and, at times, acting as informants about their activities for the police. This symbiotic relationship has allowed both these groups to benefit (Amal, 2020: 585; Budiari, 2016).

The group targets "the Other" to ensure "the purity" of religion remains intact for "the people." The police get to work to covertly appease politicians, who feel pressure to persecute "deviant" groups who "defy" religion. For its part, the members of the FPI have the opportunity to channel negative feelings-instilled through the preaching of Islamist populist leaders such as Shihab via a trauma-inducing narrative-into a physical manifestation of rage against "the Other" (Amal, 2020: 585; Budiari, 2016).

Due to the intensity of the violence associated with LPI activities, the group's leaders and street militia members have been repeatedly arrested and imprisoned for threatening the country's unity and law and order. Rizieq Shihab has twice served time for hate speech inciting LPI members to attack tourist spots or target non-Muslim and Ahmadiyya groups and villages (Jahroni, 2004: 218). While some politicians initially valued the LPI and FPI as useful counters to civil rights protests, 
these vigilantes have become harder to control and have used their street power to challenge the state (Facal, 2019; Juoro, 2019: 28; Mietzner, 2018; Hookway, 2017).

While Shihab's Salafist call for jihad has not resulted in the FPI becoming a true violent extremist group in Indonesia, it has seen its members turn to transnational populist jihad. Shihab has convinced his followers that they are not only Indonesian citizens but also part of the global ummah of Muslims and, thus, have a collective obligation to pursue global jihad against "the Western lobby" and "the Zionists" (Nuryanti, 2021; Mietzner, 2018; Hadiz, 2016).

Shihab effectively uses victimhood narratives anchored to nationalism and a faith-based identity that transcends geographical bounds. In this way, the Salafi training that thousands receive in Indonesia makes them prone to become part of the global jihad effort (Adiwilaga, Mustofa \& Rahman, 2019). This has become a very dangerous idea as today the world is more connected than ever, and jihadist groups rely upon these ideas to recruit young people (Adiwilaga, Mustofa \& Rahman, 2019). In Shihab's speeches, the "evils" and "cruelty" of the Zionists against the Palestinians is a re-occurring theme that not only talks about the plight of the Palestinians but also politicizes it an attack on every Muslim and the Islamic faith itself. There are clear indications that many have passed through the ranks of the FPI to go on to violent extremist groups such as Al Qaeda and ISIS (MEI@75, 2021; Idris, 2018: 9).

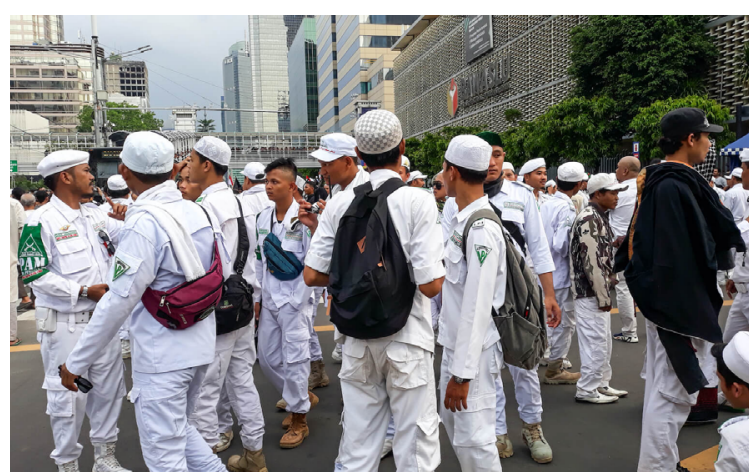

Members of The Islamic Defenders Front or Front Pembela Islam (FPI) rally in front of Indonesia election supervisory agency (Bawaslu) in Jakarta on May 10,2019

\section{The FPI a Surrogate Welfare System}

The FPI is not merely a vigilante group. The organization has established extensive networks of humanitarian aid providing relief in cases of natural disasters and assistance to the urban/suburban poor of Jakarta (Singh, 2020; Facal, 2019; Sheany, 2018). Services include education and ration packets for the poor. Shihab himself was groomed for his role in a welfarist madrasa setting, winning scholarships as he progressed from one stage of his education to the next.

Keeping this model in view, Shihab has helped the FPI develop many religious schools where children gain an Islamic education and some Arabic training as well. These schools are usually built in impoverished areas where the state has failed to reach out and address the most pressing needs of the people (Facal, 2019). The schools established by Shihab and the FPI leadership follow Salafi Wahabi teaching, which is reflected in gender segregation, strict adherence to dress codes, and other "sharia principles" (Facal, 2019). When public schools are too far from local villages or suburban homes, the proximity of the FPI madrasa gives those who would not otherwise be able to afford it a chance to educate their children. However, these seemingly altruistic establishments are places where young minds are shaped and influenced by the ideology propagated by Shihab and the FPI at large. 
Aid work has been a rich field of opportunity for the FPI to extend its influence and build its credibility. Shihab's popularity and his Saudi connections along with local supporters have allowed the FPI to establish grassroots networks of volunteers to carry out aid work that ranges from evacuating residents from flood-stricken areas to rebuilding homes, such as after the 2004 tsunami that killed hundreds of thousands in the Indonesian province of Aceh. Much of the humanitarian work was not done by the military nor the state in the immediate aftermath or long-term recovery (Sheany, 2018). One report noted that in mid-February 2004, only the TNI (the Indonesian armed forces), the Mujahedeen Council, and the FPI were the only ones actively involved in the region: "One should note that at the time the volunteers who had been working in the immediate period were already exhausted. Thus, the [aforementioned parties] seem to be the ones who work when nobody else wants to. Whereas at the initial stages, it really was not [the military] who managed the corpses' evacuation and took care of the sick and injured" (East West Center, 2005: 33). Thus, it is clear that over time, the FPI has created a synergetic relationship at the grassroots within members and communities by providing welfare services (Hookway, 2017).

When the state fails to cope with pressing social and economic issues, populist actors can effectively use dissent and direct it at political leadership. Since the FPI has been seen carrying out "altruistic" actions in the most vulnerable communities, it can draw support from there and establish its stronghold in the vacuum left by a weak state. Thus, Shihab's rhetoric has repeatedly talked about how the ulama are targeted by an "amoral" government. Therefore, the state's refusal to "repent" for its sins leaves "the people" with no choice but to carry out its own jihad to guarantee its welfare both in this world and the hereafter (Maulia, 2020; Lembaga Survei Indonesia \& Wahid Institute, 2016). With a loyal support base of followers, Shihab's self-proclaimed mission of establishing a "caliphate" or a Daulah Islam is strengthened where "the people" can practice their true faith (Salafism) "freely." The political "elite" and "minorities" are accorded little or no room in this idolized caliphate (Campbell, 2017; Hookway, 2017).

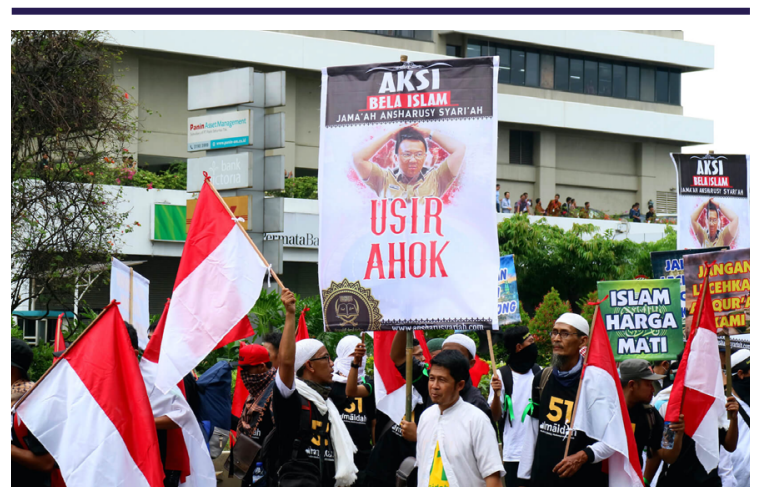

More than 200,000 Muslim protesters has descended on Jakarta to demand the governor of Jakarta, Basuki Tjahaja Purnama or Ahok, be arrested for insulting Islam on November 4, 2016.

\section{Shihab's Targeting of Ahok in Political Lobbying}

After Shihab's first arrest leading to jail time in 2003, he stepped back and restyled himself, becoming a member of the FPl's board. In 2013, he declared himself the "grand imam" of the organization. He took a less active role in leading protests but remained, as always, the face of the organization. The anti-Ahok protests showcased his charisma and power, reminding many of why the FPI remained a potential threat to the political elite of Indonesia.

Even before the protests broke out in 2016, signs of the potentially significant political power of the FPI and other right-wing political players were present. Stoking "fear" and using the rhetoric of hate while attributing the markers of moral superiority and victimhood to "the pure people," groups and leaders such as Shihab have been able to influence the writing and implementation of legislation in key areas, particular at the local level. Hookway (2017) has noted how the FPI has been able to develop social capital through its "morally driven" vigilantism and community-based activities: "In recent years, lobbying groups such as the Islamic Defenders Front (FPI) have helped introduce more than 400 Shariah-inspired laws, including those that penalize adul- 
tery, force women to wear headscarves and restrict them from going out at night" (Hookway, 2017). Sharia-inspired legislation has been passed in FPI strongholds, where its presence has been deeply entrenched with the community (Hookway, 2017).

In terms of mainstream politics, the FPI on its own never possessed a voter bank large enough to win a significant place in the parliament. With Shihab's Islamist political rhetoric, however, right-wing politicians saw a ready resource for mobilizing support on the street in the form of the FPI. Shihab has long been active in mainstream politics, and the plethora of banners and posters in communities where the FPI is deeply attached showcases support for the leader and his allies. The FPI has supported the populist politician Prabowo Subianto since 2014, and this relationship only grew in intensity following the Ahok protests in 2016.

Ahok was the Christian-Chinese deputy governor and righthand man to Joko Widodo (Jokowi) when he was governor of Jakarta. When Widodo became president, Ahok replaced him as governor. Ahok's very positive public image made him a well-liked figure, and after the 2014 victory of Jokowi, it was speculated that Ahok would be his running mate in the 2019 elections and even a possible presidential candidate for the 2024 general elections (Mietzner, 2018: 270). But before the formal announcement of Jokowi's running mate in 2016, Ahok became embroiled in a religious scandal that targeted his religious and ethnic background. He was accused of committing blasphemy when he criticized his opponents for their politicized misuse of Quranic verses against him (Nuryanti, 2021; Amal, 2020; Adiwilaga, Mustofa \& Rahman, 2019; Fossati \& Mietzner, 2019; Mietzner, 2018).

A heavily edited campaign video in which Ahok made critical comments alongside discussion of the Qur'an surfaced in 2016, and he became an instant target of attack. He was charged with blasphemy, found guilty, and sent to jail, meaning he can never hold public office again (Nuryanti, 2021). While Jokowi is a pluralist, he remained largely silent and distant during Ahok's trial and, at the end in 2019, chose a conservative Muslim running mate in the form of Ma'aruf Amin, the chair of the influential Ulama Council of Indonesia (Majelis Ulama Indonesia, MUI) (Yilmaz, 2020).

After the viral spread of the Ahok video, the MUI issued a fatwa urging the government to look into the matter as they responded to public sentiment that Ahok had committed blasphemy and harmed the sentiments of the majority of Indonesian Muslims (Nuryanti, 2021; Amal, 2020; Mietzner, 2018). Ahok's public apology following the video's surfacing and blasphemy accusations did little to satisfy the hardliners who were now able to not only attract conservative masses but even moderate Muslims (Nuryanti, 2021).

The Action to Defend Islam (Aksi Bela Islam) demonstrations were country-wide protests and sit-ins by the FPI and other right-wing parties and organizations that called for Ahok's resignation as the governor and immediate prosecution (Fealy, 2016). Ethnic Chinese business people and other members of the elite were a constant target of the FPI even before the Ahok video surfaced. The xenophobic line of attack taken by Islamist populists like Shihab had turned this group into "the Other," based on differences of faith and ethnicity. Given Indonesia's past, Shihab had instilled fear in the electorate by claiming that were national leaders selected from among the ethnic Chinese community, communism would be re-imposed in Indonesia (Seto, 2019).

Even as early as 1999, the FPI had printed banners and hung them across university campuses warning students, "Alert! Zionism and Communism penetrate all aspects of life!" (Seto, 2019). Shihab was able to forge strong alliances with opposition parties and right-wing groups as the FPI became the face of the anti-Ahok movement. By making the issue about "defending Islam," he was able to evoke deep emotion among crowds. Shihab began to describe himself as "the Great Leader of Indonesian Muslims," proclaiming a theologically grounded authority to voice the people's desire for a devout life and the removal of Islam's enemies (Fossati \& Mietzner, 2019: 774). Shihab's religious populism has thus deployed Islam as a 
tool to further his agenda and place in the political arena, mobilizing millions to march in support of the movement (Fealy, 2016; Hutton, 2018).

Rizieg Shihab's loud proclamations that the people had been "hurt" and that religion was "insulted" cast him as a defender of Islam in the eyes of many who supported the marches. In 2017, Ahok, once popular and riding high, lost his re-election bid and subsequently served time in prison. The FPI actively supported a rival candidate for governor of Jakarta. While the protests were able to create an "asymmetric multi-class alliance" between the $\mathrm{FPI}$, religious groups, and the opposition, they failed to secure a majority in the 2019 parliamentary and presidential elections. Nevertheless, the current mood points to the likelihood that the same alliance will come together to contest the 2024 general elections as well (Adiwilaga, Mustofa, \& Rahman, 2019).

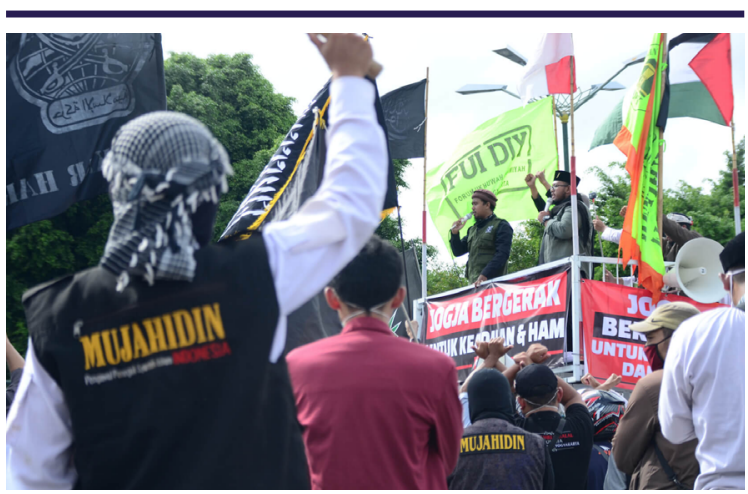

The mass action "Jogja Bergerak untuk Keadilan dan HAM" demands the release of Rizieg Shihab and the investigation of the shooting case of the FPI army in Yogyakarta, Indonesia on December 18, 2020. Photo: Hariyanto Surbakti

\section{Shihab Imprisonment and the Future of Salafism in Indonesia}

Joko Widodo was able to safeguard his political position by distancing himself from the Ahok in 2017 and staying largely silent on the protest movement. Nevertheless, following Ahok's loss in the gubernatorial elections, the government began to move against the FPI leadership. Seeing the tide turn, Shihab left Indonesia, ostensibly on a short umrah pilgrimage to Saudi Arabia. However, he remained in self-imposed exile in Saudi Arabia when it became clear that the Indonesian police were seeking him in connection with pornography charges.

During his extended sojourn in Saudi Arabia, Shihab remained active online, connecting with "the people" and constantly spewing hatred and spreading conspiracies under the banner of "defending Islam." During this time, he did not refrain from portraying the government in power as "the enemy" of "the faithful." The charges against Shihab were subsequently dropped, and he returned home, espousing a mission to lead a "moral revoIution" across Indonesia. Political analysts quickly and loudly concluded that this was simply Shihab's latest Islamist populist tactic to gain momentum ahead of the 2024 general elections (Singh, 2020).

Taking an anti-Jokowi Islamist stance amidst the COVID-19 pandemic in early 2020, Shihab was given a "hero's welcome" on his return home after nearly two years exiled in Saudi Arabia. The mass gatherings that resulted were troubling for the government because of their risk as super-spreader events. Moreover, they were politically troublesome, feeding into a general sense of despondency triggered by the economic effects of the pandemic. Indonesia was hit hard as its economy suffered greatly due to the fall-off in international tourism and periodic lockdowns (Singh, 2020). In the context of growing discontent directed toward the government, the return of the "grand imam" who promised a better future for the country and afterlife has been a worrying and unwelcome development (FR24, 2020).

Shihab made himself an increasingly large target for government prosecution. He loudly refused to get tested at a government facility for COVID-19 and continued to promote large gatherings of supporters and evoked extreme emotions busing his trademark blend of street humor, political rhetoric, and Islamist hate speech demonizing others. The day before his anticipated arrest, six young members of the FPI were shot dead in a violent confrontation with the police (Aqil, 2020). The government claimed that the victims 
were armed terrorists trying to destabilize the country's law and order. Shihab was arrested for violating COVID-19 regulations, and the FPI was banned as various members and key leaders were found to be involved in inciting violence (Kelemen, 2021).

Shihab voluntarily handed himself over to the authorities. In the eyes of his followers, this casts him as a martyr and the government as "tyrannical." In custody in March 2021, he refused to participate in his trial (held remotely by video link), signaling non-compliance by reciting verses from the Qur'an whenever the court sought to question or otherwise engage with him, and his behavior delayed the trial. Since being sentenced, the Indonesian government has refused to disclose his location for fear of drawing large crowds of protesters and supporters (detikNews, 2021). 


\section{CONCLUSION}

While Shihab's immediate future hangs in the balance, there is certainty regarding Islamist populism in Indonesia. Shihab is not the only populist political actor in the country who has used Islamism to build a following. It is still unclear how the disbanded FPI leadership will regroup around the 2024 elections. The sudden ban, the shooting deaths of supporters, and the use of COVID-19 lockdown legislation to arrest Shihab have only served to cast him as a holy martyr in the eyes of his followers.

At the same time, the efficacy of exploiting religious sentiment to generate fear has compounded the power of populist Islamism in Indonesian life. Shihab's radical Salafist message continues to inspire thousands to action. The FPI may be outlawed, but tens of thousands of FPI activists can regroup under new banners or join or form similar groups. Even behind bars, evidence of Shihab's political power is displayed by the fact that his location is kept secret due to fear of protests and riots outside the jail. Shihab's courtroom theatrics involving the recitation of the Qur'an to delay his trial while displaying his "heroic piety" show the enduring power and efficacy of Islamist populism in Indonesia. 


\section{REFERENCES}

- (2005). "After the Tsunami." East West Centre. https://www.preventionweb.net/

files/715_9451.pdf (accessed on April 29, 2021).

- (2016). The potential of radicalism and socio-religious intolerance among Indonesian Muslims. Lembaga Survei Indonesia and Wahid Institute. Jakarta: LSI.

- (2020). "Rizieq Shihab, back in Indonesia, calls for "moral revolution"." FR24 News.

December 2, 2020. https://www.fr24news.com/a/2020/12/rizieq-shihab-back-in-indonesia-calls-for-moral-revolution.html (accessed on April 30, 2021).

- (2021). "The moment when the ex-head of FPI walked out but could not leave the room at Bareskrim." detikNews. March 19, 2021. https://news.detik.com/berita/d-5500041/momeneks-ketum-fpi-walkout-tapi-tak-bisa-keluar-ruangan-di-bareskrim (accessed on April 30, 2021).

— (2021). "Jihadi Recruitment and Return: Asian Threat and Response." MEI@75. January 1, 2021. https://www.mei.edu/publications/jihadi-recruitment-and-return-asian-threat-and-response (accessed on April 29, 2021).

Adiwilaga, Rendy; Mustabsyirotul, Mustofa, U. and Ridha, Rahman, R. (2019). "Quo Vadis Islamic Populism? An Electoral Strategy." Central European Journal of International and Security Studies. 13(4), 432-453.

Aqil. I. M. A. (2020). "FPI calls for transparency, justice as bodies of slain supporters laid to rest." Jakarta Post. December 10, 2020. https://www.thejakartapost.com/news/2020/12/10/ fpi-calls-for-transparency-justice-as-bodies-of-slain-supporters-laid-to-rest.html (accessed on April 29, 2021).

Amal, K. M. (2020). "Islamic Populism in Southeast Asia: An Indonesian Muslim Intellectuals Perspective." Journal of Critical Reviews. 7(5).

Baer, M., Makdisi, U., \& Shryock, A. (2009). "Tolerance and Conversion in the Ottoman Empire: A Conversation." Comparative Studies in Society and History. 51(4), 927-940.

Barton, Greg. (2021). "Contesting Indonesia's Democratic Transition: Laskar Jihad, the Islamic Defenders Front (FPI) and Civil Society." In: Vandenberg, Andrew and Zuryani, Nazrina (Eds.) Security, Democracy, and Society in Bali. Singapore: Palgrave Macmillan, p.305331.

Barton, Greg. (2020). "The Historical Context and Regional Social Network Dynamics of Radicalisation and Recruitment of Islamic State Foreign Terrorist Fighters in Indonesia and its Southeast Asian Neighbours." In: La Toya Waha (ed.) United by Violence, Divided by Cause: A Comparison of Drivers of Radicalisation and Violence in Asia and Europe. BadenBaden: Nomos/KAS, p.117-140.

Barton, Greg. (2020). "Salafist-jihadism in Southeast Asia." In: Isaac Kfir and John Coyne. Counterterrorism Yearbook 2020. Canberra: ASPI. Po. 43-51.

Benjamin, Medea. (2016). Kingdom of the Unjust: Behind the U.S.-Saudi Connection. New York: OR Books.

Bouma, G.D.; Ling, R.; Pratt, D. (2010). "Indonesia." In: Religious Diversity in Southeast Asia and the Pacific. Springer, Dordrecht. 
Budiari, Indra. (2018). "After FPI tipoff, police raid alleged gay sex party, arrest 13." The Jakarta Post. November 28, 2018. https://www.thejakartapost.com/news/2016/11/28/after-fpitipoff-police-raid-alleged-gay-sex-party-arrest-13.html (accessed on April 29, 2021).

Campbell, Charlie. (2017). "ISIS Unveiled: The Story Behind Indonesia's First Female Suicide Bomber." Time. March 3, 2017. https://time.com/4689714/indonesia-isis-terrorism-jihad-extremism-dian-yulia-novi-fpi/ (accessed on April 29, 2021).

Choksy, Carol E. B. \& Choksy, Jamsheed K. (2015). "The Saudi Connection: Wahhabism and Global Jihad." World Affairs. 178(1), 23-34.

Dillon, Michael R. (2009). "Wahhabism is it a factor in the spread of global terrorism?" Calhoun: The NPS Institutional. https://www.nps.edu/documents/105988371/107571254/DillonWahhabismThesis.pdf/23fc46fb-17a6-41da-83b8-8e312191b5bb (accessed on April 29, 2021).

Facal, G. (2019). "Islamic Defenders Front Militia (Front Pembela Islam) and its Impact on Growing Religious Intolerance in Indonesia." TRaNS: Trans -Regional and -National Studies of Southeast Asia. 1-22.

Fealy, Greg. (2016). "Bigger than Ahok: explaining the 2 December mass rally." Indonesia at Melbourne. September 26, 2016. http://indonesiaatmelbourne.unimelb.edu.au/bigger-than-ahok-explaining-jakartas-2-december-mass-rally/ (accessed on April 30, 2021).

Fossati, O. Diego \& Mietzner, Marcus. (2019). "Analyzing Indonesia's Populist Electorate." Asian Survey. 59(5), 769-794.

Freeman, Michael et al. (2021). The Global Spread of Islamism and the Consequences for Terrorism. University of Nebraska Press.

Gawrych, George W. (1983). "Tolerant Dimensions of Cultural Pluralism in the Ottoman Empire: The Albanian Community, 1800-1912." International Journal of Middle East Studies. 15 (4), 519-536.

Ghoshal B. (2010). "Arabization: The Changing Face of Islam in Asia." India Quarterly. 66(1), 69-89.

Gubbay, Lucien. (2000). "The Rise, Decline and Attempted Regeneration of The Jews Of The Ottoman Empire." European Judaism: A Journal for the New Europe. 33(1) 59-69.

Hadiz, Vedi R. (2018). "Imagine All the People? Mobilising Islamic Populism for Right-Wing Politics in Indonesia." Journal of Contemporary Asia. 48: 566-83.

Hadiz, Vedi R. (2016). Islamic Populism in Indonesia and the Middle East. Cambridge and New York: Cambridge University Press.

Hamid, Shadi \& Dar, Rashid. (2016). "Islamism, Salafism, and jihadism: A primer." Bloomberg. July 15, 2016. https://www.brookings.edu/blog/markaz/2016/07/15/islamism-salafism-and-jihadism-a-primer/ (accessed on April 29, 2021).

Hookway, James. (2017). "Curfews, Obligatory Prayers, Whippings: Hard-Line Islam Emerges in Indonesia." The Wallstreet Journal. September 13, 2017. https://www.wsj.com/articles/ indonesia-once-a-model-of-moderate-islam-slides-toward-a-harder-line-1505311774 (accessed on April 29, 2021).

Hutton, Jeffrey. (2018). "Prabowo vs Widodo: What Makes General Think Indonesian Election will be a case of Second Time Lucky?" SCMP. March 17, 2018. http://www.scmp.com/ week-asia/politics/article/2136558/prabowo-vs-widodo-what-makes-general-think-indonesian-election (accessed on April 30, 2021). 
Idris, Iffat. (2018). "Youth vulnerability to violent extremist groups in the Indo-Pacific." GSDRC. https://gsdrc.org/wp-content/uploads/2018/10/1438-Youth-Vulnerability-to-Violent-Extremist-Groups-in-the-Indo-Pacific.pdf (accessed on April 29, 2021).

Jahroni, J. (2004). “Defending the Majesty of Islam: Indonesia's Front Pembela Islam (FPI) 1998-2003." Studia Islamika. 11(2), 197-256.

Junior, Ibnu Umar. (2017). Biography of Habib Rizieq Shihab: singa Allah dari negeri timur: the legend. Jakarta: Pujangga Tunggal.

Juoro, Umar. (2019). "The Rise of Populist Islam in Indonesia." Turkish Policy Quarterly. 18(3).

Kelemen, Barbara. (2021). "COVID-19 Fuels the Return of Islamism in Indonesia.” MEI@75. March 16, 2021. https://www.mei.edu/publications/covid-19-fuels-return-islamism-indonesia (accessed on April 30, 2021).

Lewis, Bernard. (1980). "The Ottoman Empire and Its Aftermath." Journal of Contemporary History. 15(1) 27-36.

McDonnell, Duncan \& Ondelli, Stefano. (2020). "We compared the language of populist leaders with their mainstream opponents - the results were unexpected." The Conversation. November 3, 2020. https://theconversation.com/we-compared-the-language-ofpopulist-leaders-with-their-mainstream-opponents-the-results-were-unexpected-148343 (accessed on April 29, 2021).

Miodownik, Dan \& Barak, Oren. (2014). Nonstate Actors in Intrastate Conflicts. University of Pennsylvania Press.

Mietzner, Marcus. (2018). "Fighting Illiberalism with Illiberalism: Islamist Populism and Democratic Deconsolidation in Indonesia." Pacific Affairs. 91(2).

Maulia, Erwida. (2020). "How firebrand cleric Habib Rizieq plans to Islamize Indonesia." Nikkei Asia. November 24, 2020. https://asia.nikkei.com/Spotlight/Islam-in-Asia/How-firebrand-cleric-Habib-Rizieq-plans-to-Islamize-Indonesia (accessed on April 29, 2021).

Moffitt, Benjamin. (2016). The Global Rise of Populism: Performance, Political Style, and Representation. Palo Alto: Stanford UP.

Nai, Alessandro \& Martínez, Ferran. (2019). "The personality of populists: provocateurs, charismatic leaders, or drunken dinner guests?" West European Politics. 42(7), 1337-1367.

Nuryanti, Sri. (2021). "Populism in Indonesia: Learning from the 212 Movement in Responseto the Blasphemy Case against Ahok in Jakarta." In: Populism in Asian Democracies. Sook Jong Lee, Chinen Wu and Kaustuv Kanti Bandyopadhyay. Boston: Brill.

Rijal, Syamsul. (2019). "Performing Arab Saints and Marketing the Prophet: Habaib and Islamic Markets in Contemporary Indonesia." Archipel, 189-213.

Seto, A. (2019). "Islamist buzzers: Message flooding, offline outreach, and astroturfing." Austrian Journal of South-East Asian Studies. 12(2), 187-208.

Singh, Bilveer. (2020). "What Does Rizieq Shihab's Return Mean for Indonesian Politics?." The Diplomat. December 4, 2020. https://thediplomat.com/2020/12/what-does-rizieq-shihabs-return-mean-for-indonesian-politics/ (accessed on April 30, 2021).

Varagur, Krithika. (2020). "How Saudi Arabia's religious project transformed Indonesia." The Guardian. April 16, 2020. https://www.theguardian.com/news/2020/apr/16/how-saudi-arabia-religious-project-transformed-indonesia-islam (accessed on April 29, 2021). 
Vergani, M.; Iqbal, M.; Ilbahar, E.; Barton, G. (2020). "The 3 Ps of radicalisation: push, pull and personal. A systematic scoping review of the scientific evidence about radicalisation into violent extremism." Studies in Conflict \& Terrorism.43(10), 854.

Wilson, Ian. (2015). The Politics of Protection Rackets in Post-New Order Indonesia: Coercive Capital, Authority and Street Politics. London: Routledge.

Woodward, M.; Yahya, M.; Rohmaniyah, I. et al. (2014). "The Islamic Defenders Front: Demonization, Violence and the State in Indonesia." Contemporary Islam. 8, 153-171.

Yilmaz, Ihsan. (2020). "Indonesia Country Profile of Populism." European Center for Populism Studies. https://populismstudies.org/tag/indonesia/ (accessed on April 29, 2021).

Yilmaz, Ihsan; Morieson, Nicholas \& Demir, Mustafa. (2021). "Exploring Religions in Relation to Populism: A Tour around the World." Religions. 12(5): 301.

Yilmaz, Ihsan. (2021a). “Erdogan's Political Journey: From Victimised Muslim Democrat to Authoritarian, Islamist Populist." European Center for Populism Studies. https://www.populismstudies.org/erdogans-political-journey-from-victimised-muslim-democrat-to-authoritarian-islamist-populist (accessed on April 29, 2021).

Yilmaz, Ihsan. (2021b). Creating the Desired Citizen: Ideology, State and Islam in Turkey. Cambridge and New York: Cambridge University Press. 


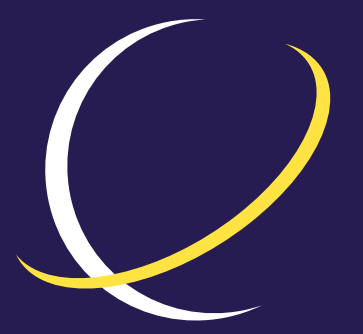

\section{ECPS \\ EUROPEAN CENTER for POPULISM STUDIES}

\section{ABOUT ECPS}

The European Center for Populism Studies (ECPS) is an independent, nonpartisan, nonprofit organization, based in Brussels, for research on and analysis of challenges posed by the resurgence of political populism. ECPS facilitates collaboration among networks of academic experts, practitioners, policymakers, media, and other stakeholders. ECPS offers a platform for the exchange of policy solutions on issues relating to rising populism and provides insights for policy-making and critical analysis to raise broader awareness and engagement through:

\section{Publications}

\section{Academic publications}

Policy reports

White papers

Commentaries

Podcasts and interviews with experts

Events, seminars, workshops, and conferences

\section{Research Programs}

Authoritarianism

Digital Populism

Economics

Environment \& Climate

Extremism \& Radicalisation

Gender

Human Rights

Foreign Policy

Leadership \& Persona

Migration

\section{ECPS Youth Program}

ECPS Academy 